\title{
Influence of Weight Loss, Body Composition, and Lifestyle Behaviors on Plasma Adipokines: A Randomized Weight Loss Trial in Older Men and Women with Symptomatic Knee Osteoarthritis
}

\author{
Gary D. Miller, ${ }^{1}$ Monica Z. Jenks, ${ }^{2}$ Mandolyn Vendela, ${ }^{1}$ \\ James L. Norris, ${ }^{3}$ and Gloria K. Muday ${ }^{2}$ \\ ${ }^{1}$ Department of Health and Exercise Science, Wake Forest University, Reynolda Station, P.O. Box 7868 Winston-Salem, \\ NC 27109, USA \\ ${ }^{2}$ Department of Biology, Wake Forest University, Winston-Salem, NC 27109, USA \\ ${ }^{3}$ Department of Mathematics, Wake Forest University, Winston-Salem, NC 27109, USA
}

Correspondence should be addressed to Gary D. Miller, millergd@wfu.edu

Received 31 August 2012; Revised 15 November 2012; Accepted 19 November 2012

Academic Editor: Renato Pasquali

Copyright ( 2012 Gary D. Miller et al. This is an open access article distributed under the Creative Commons Attribution License, which permits unrestricted use, distribution, and reproduction in any medium, provided the original work is properly cited.

\begin{abstract}
Objective. To investigate effects of weight loss on adipokines and health measures in obese older adults with symptomatic knee osteoarthritis. Methods. Participants were randomly assigned to either weight loss (WL) (men: 12, women: 14) or weight stable (WS) group (men: 12, women: 13). WL intervention included meal replacements and structured exercise training. Measurements of leptin, adiponectin, soluble leptin receptor, lifestyle behaviors, and body composition were collected at baseline and 6 months. Univariate analysis of covariance was performed on 6 month variables, and Spearman and partial correlations were made between variables. Results. Weight loss was $13.0 \%$ and $6.7 \%$ in WL for men and women, respectively. Women in WL had lower whole body and trunk fat than WS. The leptin : adiponectin ratio was lower for women in WL than WS at 6 months, with no group differences in adipokines for men. Leptin and free leptin index correlated with body fat in both genders at baseline. Interestingly, only women showed reductions in leptin $(P<0.100)$ and correlations between the percentage change leptin and trunk fat and the percentage changes in free leptin index with total fat and trunk fat. Partial correlations between 6 month adipokines after adjustments for covariates and group/time period show potential multivariate influences. Conclusions. In the presence of an effective weight loss intervention in older obese adults, there are significant relationships between weight and fat loss and leptin in women, but not men, suggesting gender-specific features of adipokine metabolism in this age group.
\end{abstract}

\section{Introduction}

Obesity is increasing rapidly in the American population; currently $69.2 \%$ of all American adults are overweight (Body Mass Index $(\mathrm{BMI}) \geq 25 \mathrm{~kg} / \mathrm{m}^{2}$ ) or obese $\left(\mathrm{BMI} \geq 30 \mathrm{~kg} / \mathrm{m}^{2}\right)$ [1]. Concurrent with this rise in obesity, there is an increase in our aging American population. According to the 2010 US census, more than 50 million people are currently $\geq 62$ years in age, and approximately $70 \%$ of the aged population are overweight or obese [1], with continuing annual increases. This rise in overweight and obesity among older adults is especially troublesome because numerous diseases are associated with excess body fat and aging, including type 2 diabetes, hypertension, dyslipidemia, coronary heart disease, and osteoarthritis [2].

Recent research has led to the recognition that adipose tissue not only stores energy but also is an active endocrine organ that secretes peptide hormones termed adipokines $[3,4]$. Increases in adiposity alter a number of physiological processes, including energy metabolism, inflammation, and insulin sensitivity $[5,6]$. More than 50 adipokines, including leptin and adiponectin, have been studied to determine their 
functions and roles in obesity and related comorbidities [7]. Leptin is a peptide hormone produced by adipocytes suppresses appetite and stimulates energy usage, but leptin also has immune-modulating activity [5]. Leptin signaling occurs through a membrane receptor, with several splice variants identified, as well as a soluble form. The long receptor in the hypothalamus is considered the main sensor for satiety signaling [5]. Additionally, the soluble leptin receptor (sLR), which binds leptin as it circulates in the blood, may be important for regulating leptin's actions by protecting leptin from degradation or by blocking its activity $[5,8-10]$. Adiponectin is also secreted by adipocytes and is considered protective against type 2 diabetes and cardiovascular disease, due to its anti-inflammatory effects $[3,5]$. Elevated leptin levels have been observed during disease states, such as obesity, metabolic syndrome, atherosclerosis, and diabetes. In contrast, levels of adiponectin have been associated with these diseases [3]. By delineating the conditions that regulate the accumulation of these adipokines and their soluble receptors, behavioral and pharmacological interventions may be targeted to alter their levels to improve clinical conditions.

It is well recognized that levels of leptin and adiponectin are linked to the amount of body fat, with leptin having a direct relationship $[5,7,10-17]$ and adiponectin an inverse relationship $[5,7,10,15]$. A number of studies have shown increases in adiponectin and/or reductions in leptin with weight loss interventions, mostly in younger adults [11-14], but there are few studies in older adults. However, even when corrected for body fat, there is still considerable variation among individuals in the plasma levels of these adipokines. This variance is likely attributed to factors other than body composition, which may include gender, acute body energy imbalance, dietary intake, body fat distribution, physical activity levels, race/ethnicity, and cardiovascular fitness [3, 15-23]. Additionally, levels of soluble leptin receptor and the free leptin index, a measure of the ratio of leptin: soluble leptin receptor [24], may add to the variability. Furthermore, body fat content is correlated with plasma leptin in young men and women, but not in elderly subjects [25], which may contribute to the increased prevalence of obesity occurring with age.

There is also evidence to indicate that adipokines may be a critical mediator of obesity-related osteoarthritis, which is significant in that the current cohort being studied was recruited based on having symptomatic knee osteoarthritis. Leptin's relationship with osteoarthritis is likely multifactorial, including its synergistic action with inflammatory cytokines and growth factors such as transgenic growth factor b, a known stimulator of osteophyte formation; cell proliferation; repair processes of osteoarthritis; stimulation of nitric oxide production in chondrocytes; and limiting blood supply to the joint and impairing cartilage health [26-30]. In a cross-sectional study, adipokines, including leptin and adiponectin, were all higher in individuals with osteoarthritis compared to controls, but none of the adipokines were related to markers of cartilage damage [31].

There are scant data that investigate associations between adipokines and demographic, lifestyle, and metabolic factors in a randomized controlled trial in older adults. The few studies that have examined this area were limited in that they lacked control groups, were cross-sectional in design, failed to examine these key adipokines collectively, examined only healthy individuals, or did not look at the variety of factors together [33]. Therefore, our primary aim was to determine the adiponectin, leptin, and sLR responses to a weight loss intervention encompassing dietary restriction and exercise training compared to a weight stable control group in a randomized clinical trial in older obese men and women. Secondarily, we aimed to test the relationships between preand post-weight loss adipokine values with a number of lifestyle and body composition measures in men and women, separately.

\section{Methods}

2.1. Study Population. Data for this investigation and analysis were obtained from the physical activity, inflammation, and body composition Trial (PACT), which recruited obese (BMI $\left.\geq 30.0 \mathrm{~kg} / \mathrm{m}^{2}\right)$ men and women. Details of this trial are described elsewhere $[32,34]$ but did not include the data reported here assessing 3 adipokine measurements and the effect of weight loss and gender on these values. Recruitment was performed through advertisements in newspapers, placement of brochures in clinics and physician offices, and contacting older adults who had participated in previous research in our clinical research center facility. Participants were randomly assigned to one of two groups: intensive weight loss (WL) group and weight stable (WS) control group. The WL group had a 10\% weight loss goal and consisted of a 6 month dietary restriction and supervised exercise training program. The WS group received bimonthly healthy lifestyle information sessions. Eligibility criteria included a sedentary lifestyle, age of $\geq 60$ years, symptomatic knee osteoarthritis (OA), and self-reported difficulty attributed to knee pain in performing at least one of the following activities: lifting and carrying groceries, walking one-quarter mile, getting in and out of a chair, or going up and down stairs. Exclusion criteria included any unstable medical conditions or conditions where rapid weight loss or exercise is contraindicated (e.g., unstable angina, frailty, and advanced osteoporosis). In addition they were excluded from the study if they (1) were unwilling to modify diet or physical activity patterns or would not be able to comply with the intervention because of food allergies or reactions to the meal replacements; (2) if they lived $>50$ miles from the treatment center; or (3) if they had a history of alcohol abuse. All eligible participants understood the expectations from the study and gave written informed consent to participate in the study according to the guidelines of the Wake Forest University Institutional Review Board, which reviewed and approved the initial study and these continuing analyses.

\subsection{Interventions}

2.2.1. Intensive Weight Loss (WL). The primary goal for this intervention included a $10 \%$ weight loss from initial body weight in a six month period. The weight loss intervention 
included partial meal replacements, nutrition education, and lifestyle behavior modifications, such as exercise. Initial diet plans were set at an energy deficit of $1000 \mathrm{kcals} /$ day via dietary intake restrictions and meal replacements (SlimFast shakes and bars). The third meal was tailored to allow for individual preferences for various food items, while meeting the caloric restrictions.

Behavioral and educational sessions were held once a week, and sessions lasted for 60 minutes/group $(n=6-12$ per group). Sessions included advice on food selection, meal portion, dietary fat control, relapse prevention, and selfmonitoring techniques.

Participants also engaged in exercise training sessions 3 days a week for 60 minutes per session. Exercise programs consisted of a warm-up phase ( 5 minutes), an aerobic phase (15 minutes), a strength phase (20 minutes), a second aerobic phase ( 15 minutes), and a cool-down phase ( 5 minutes). The exercise intensity for the aerobic portion was $50-85 \%$ of the age-predicted heart rate reserve. Strength training included four stations: leg extension, leg curl, heel raise, and step-ups using ankle cuff weights, weight vest, and resistance training equipment. Two sets of 12 repetitions were performed at each station with progression of resistance as strength improved. Pedometers were distributed to the participants, and counts (steps) were recorded daily on self-monitoring logs provided. Participants were instructed to accumulate 10,000 steps per day as a goal.

2.2.2. Weight Stable (WS). Participants randomized to this group served as the control group and met twice a month in a group setting with presentations on general health, including osteoarthritis and exercise. Individuals were weighed at these meetings and encouraged to maintain their weight through the 6 month period. In addition, participants received bimonthly newsletters, addressing such topics as nutrition, disease, and aging. Upon the study's close, weight stable participants were provided with the weight loss information on diet and exercise and a supply of meal replacements and snack foods, as well as a personalized exercise consultation and access to the facility-based exercise program as an incentive and reward for participation in the study.

2.2.3. Procedures. Individuals reported to the General Clinical Research Center (GCRC) on their assigned testing days at baseline and again upon completion of the 6 month intervention. During each visit, body weight and height were obtained by a member of the GCRC nursing staff. Participants also underwent a dual energy X-ray absorptiometry (DXA; Hologic Delphi QDR) scan, where percentage, absolute total body fat, and trunk fat measures were obtained. At baseline only, a graded exercise treadmill test using a symptom-limited modified Naughton protocol was administered to achieve peak workload. Estimated peak metabolic equivalents (METS) were determined based on stage achieved on the treadmill test. Physical activity was assessed by pedometers. Each participant was given a pedometer to wear around his/her waist for a 7 day period. This collected the number of step counts per day. An average daily step count for the week was calculated and used in the analysis. Dietary intake was obtained from a 3 day food record taken at both testing periods. Nutrient analysis from the food records was performed using the Minnesota Nutrition Data System (NDS). Three-day averages of macronutrients and total energy intake were determined at baseline and 6 month followup.

Whole blood samples were collected in EDTA-treated vacutainers via venipuncture from an antecubital vein in the early morning (between 7-9 AM) after a $12 \mathrm{hr}$ fast. Samples were put immediately on ice and separated by centrifugation for 20 minutes at $4^{\circ} \mathrm{C}$ within 30 minutes of collection. After separation, specimens were stored in $1 \mathrm{~mL}$ aliquots at $-20^{\circ} \mathrm{C}$ until analyses for adipokines were performed. Plasma concentrations of leptin and adiponectin were determined using enzyme-linked immunosorbent assays using ELISA kits from Millipore Corporation (Billerica, MA). Soluble leptin receptor plasma concentrations were determined using Quantikine ELISA kits from R\&D Systems (Minneapolis, $\mathrm{MN}$ ). All samples were measured in duplicate, and the average of the two values was used for data analyses. Duplicate samples that did not provide a coefficient of variation of less than $6 \%$ were reanalyzed. The intra-assay and interassay CVs for all adipokines were $\leq 6 \%$. Leptin samples were diluted $1: 4$, adiponectin samples were diluted $1: 500$, and soluble leptin receptor samples were diluted $1: 5$.

Free leptin index was calculated from the ratio of leptin: soluble leptin receptor $\times 100$ according to Kratzsch et al. [24] The leptin to adiponectin ratio was calculated. The ratio of leptin to fat mass was also determined, and all ratios were used in the data analysis.

2.2.4. Data Analysis. Eighty-seven participants were randomized to either the weight stable (WS) $(n=43)$ or weight loss (WL) $(n=44)$ group with 8 participants dropping out of the study due to lack of time, transportation issues, undisclosed reasons, or not being randomized to desired intervention group. Seventy-nine $(n=38$ for WS and $n=41$ for $\mathrm{WL}$ ) individuals yielded data for at least part of the follow-up measures at 6 months with a total of 51 participants $(n=25$ for WS and $n=26$ for WL) having data for leptin, adiponectin, and soluble leptin receptor at both time points. The primary reason for the (79-51) difference was insufficient plasma to perform assays at both time points.

Due to substantial differences between genders, data were separated by gender for all intervention analyses. Data were checked for normality using histograms to show frequencies, and skewness was examined by multiplying the standard error of skewness by two and determining if the level of skewness was either \pm 1 of this value. The hormone and receptor concentrations were not normally distributed; therefore they were transformed using log conversions. Means and standard error of the mean were determined at both baseline and 6 months for body weight $(\mathrm{kg})$, body weight loss (\%), body mass index (BMI, $\mathrm{kg} / \mathrm{m}^{2}$ ), total body fat $(\mathrm{kg})$, trunk fat $(\mathrm{kg})$, total body fat $\%$, GXT peak METS level (baseline only), step counts, macronutrient and energy intake, and hormonal and receptor plasma concentrations at each time period. 
TABLE 1: Baseline demographics and medical history for participants categorized as total completers, dropouts, or incomplete data, and completers by randomized group.

\begin{tabular}{|c|c|c|c|c|}
\hline Variable & $\begin{array}{l}\text { Total completers } \\
\qquad N=51\end{array}$ & $\begin{array}{l}\text { Dropouts or incomplete data } \\
\qquad N=36\end{array}$ & $\begin{array}{l}\text { Weight stable } \\
\qquad N=25\end{array}$ & $\begin{array}{l}\text { Weight loss } \\
\quad N=26\end{array}$ \\
\hline Age, years & $69.3(0.9)$ & $69.8(0.8)$ & $69.3(1.3)$ & $69.3(1.3)$ \\
\hline Weight, kg & $101.2(2.4)$ & $92.9(2.5)^{*}$ & $101.8(3.0)$ & $102.6(4.8)$ \\
\hline Body mass index, $\mathrm{kg} / \mathrm{m}^{2}$ & $35.0(0.6)$ & $34.0(0.7)$ & $34.9(0.8)$ & $35.7(1.3)$ \\
\hline Maximal work capacity, estimated METS & $5.8(0.2)$ & $5.6(0.2)$ & $5.9(0.2)$ & $6.0(0.2)$ \\
\hline Gender, women (\%) & $52.9(7.0)$ & $77.8(7.0)^{*}$ & $52.0(10.2)$ & $53.9(10.0)$ \\
\hline Race, white (\%) & $88.0(5.6)$ & $80.6(6.7)$ & $96.0(4.0)$ & $80.0(8.2)$ \\
\hline $\begin{array}{l}\text { Experience chest pain, shortness of breath, } \\
\text { other breathing difficulties, yes (\%) }\end{array}$ & $20.4(5.8)$ & $29.4(8.0)$ & $16.7(7.8)$ & $24.0(8.7)$ \\
\hline Experience injuries or falls, yes (\%) & $10.0(4.3)$ & $17.7(6.6)$ & $8.0(5.5)$ & $12.0(6.6)$ \\
\hline \multicolumn{5}{|l|}{$\begin{array}{l}\text { Has a doctor ever told you that you had any of the } \\
\text { following? yes }(\%)\end{array}$} \\
\hline Angina & $10.4(4.4)$ & $8.6(4.8)$ & $4.3(4.3)$ & $16.0(7.5)$ \\
\hline Congestive heart failure & $0.0(0.0)$ & $0.0(0.0)$ & $0.0(0.0)$ & $0.0(0.0)$ \\
\hline Palpitations, irregular heartbeat, or heart surgery & $22.5(6.0)$ & $14.7(6.1)$ & $20.0(8.2)$ & $25.0(9.0)$ \\
\hline Heart attack & $6.0(3.4)$ & $5.7(4.0)$ & $4.0(4.0)$ & $8.0(5.5)$ \\
\hline High blood pressure & $65.3(6.9)$ & $52.9(8.7)$ & $64.0(9.8)$ & $66.7(9.8)$ \\
\hline Cancer & $22.0(5.9)$ & $17.7(6.6)$ & $24.0(8.7)$ & $20.0(8.1)$ \\
\hline Diabetes & $20.0(5.7)$ & $18.2(6.8)$ & $16.0(7.5)$ & $24.0(8.7)$ \\
\hline $\begin{array}{l}\text { Emphysema, bronchitis, asthma, breathing difficulties, } \\
\text { or lung problems }\end{array}$ & $19.2(5.8)$ & $23.5(7.4)$ & $24.0(8.7)$ & $13.6(7.5)$ \\
\hline Kidney disease & $2.0(2.0)$ & $8.6(4.8)$ & $0.0(0.0)$ & $4.0(4.0)$ \\
\hline $\begin{array}{l}\text { Poor circulation of your legs or leg cramping when } \\
\text { walking }\end{array}$ & $12.0(4.6)$ & $21.9(7.4)$ & $8.0(5.5)$ & $16.0(7.5)$ \\
\hline Stroke or TIA & $4.0(2.8)$ & $2.9(2.9)$ & $4.0(4.0)$ & $4.0(4.0)$ \\
\hline
\end{tabular}

Values are presented as means (standard error of mean).

* Indicates $P<0.050$ for comparison between total completers column and dropouts or incomplete data column.

Analysis for the effect of the intervention on the variables listed above was conducted using univariate analysis of covariance. These analyses were performed on 6 month outcomes of body composition, dietary intake, step counts, and the log values for the adipokines; the nontransformed values for the adipokines are also shown for ease of understanding (Table 3). The covariates include age, race, and baseline values for the specific variables. Results are shown as estimated marginal means \pm standard error of the mean, confidence intervals, $P$ value difference levels, and power of detection cutoffs. Partial correlations between 6 month adipokines after adjustments for covariates and groups/time periods are used to examine potential multivariate influences between the adipokines. The power of a $t$-test on a mean is 0.50 (i.e., $50 \%$ ) when the absolute value of the true population mean value equals the half-width of the $95 \%$ confidence interval. Powers will be larger than $50 \%$ for more extreme means and less than $50 \%$ for less extreme true means. Spearman rank order correlations were performed between the adipokines and body composition, step counts, macronutrient and total energy intake, and initial METS from GXT for measures at baseline and 6 months. Frequencies were also obtained for gender, race, and medical history. Independent two-sample $t$-tests were used to compare demographic and medical history measures between the group of 51 participants included in all analyses and the group of 36 individuals that dropped out or had incomplete data. Additionally, comparisons for these measures were made between the WS and WL groups. All statistical analyses were performed using SPSS 19.0 (Chicago, IL), and statistical significance was set at $P<0.050$.

\section{Results}

We examined 51 participants who were randomized to either weight stable (WS) $(n=25$; men: 12 ; women: 13$)$ or weight loss (WL) $(n=26$; men: 12 ; women: 14$)$ groups. There were no significant differences in demographics, initial body weight, BMI, and medical history between the WS and WL groups (Table 1). In our initial population, body weight was matched between groups, but because more women than men dropped out of the study or had insufficient plasma samples, the initial body weights were no longer matched between WL and WS groups. For the 51 randomized participants included in the adipokine analysis, their medical history showed that nearly two-thirds had high blood pressure, while $22 \%$ had palpitations, arrhythmia, or heart surgery, 22\% had cancer, and 20\% had diabetes. Most of 
TABLE 2: Measures of body weight and body composition outcomes and diet and physical activity behaviors at baseline and 6 month followup separated by gender. Statistical analysis was performed on 6 month values.

\begin{tabular}{|c|c|c|c|c|c|c|}
\hline \multirow{2}{*}{ Variable } & \multicolumn{2}{|c|}{ Weight stable } & \multicolumn{2}{|c|}{ Weight loss } & \multicolumn{2}{|c|}{$\begin{array}{c}95 \% \text { confidence interval } \\
\text { \{cutoff for } 50 \% \text { power }\} \\
\text { for mean difference } \\
\text { (WL - WS) at } 6 \text { Month }\end{array}$} \\
\hline & $\begin{array}{c}\text { Men } \\
(n=12)\end{array}$ & $\begin{array}{l}\text { Women } \\
(n=13)\end{array}$ & $\begin{array}{c}\text { Men } \\
(n=12)\end{array}$ & $\begin{array}{l}\text { Women } \\
(n=14)\end{array}$ & Men & Women \\
\hline \multicolumn{7}{|l|}{ Weight, kg } \\
\hline Baseline & $110.3(5.3)$ & $94.6(3.8)$ & $121.3(2.8)$ & $90.7(3.6)$ & & \\
\hline 6 months & $111.4(2.7)$ & $92.9(1.4)$ & $101.3(3.0)$ & $87.2(1.3)$ & $\begin{array}{c}(-18.9,-1.4)^{*} \\
\{ \pm 8.8\}\end{array}$ & $\begin{array}{c}(-9.8,-1.6)^{*} \\
\{ \pm 4.1\}\end{array}$ \\
\hline Weight change (\%) & $-1.0(2.1)$ & $0.6(1.6)$ & $-13.0(2.3)$ & $-6.7(1.6)$ & $\begin{array}{c}(-18.7,-5.3)^{*} \\
\{ \pm 6.7\}\end{array}$ & $\begin{array}{c}(-12.1,-2.4)^{*} \\
\{ \pm 4.9\}\end{array}$ \\
\hline \multicolumn{7}{|c|}{ Body mass index, $\mathrm{kg} / \mathrm{m}^{2}$} \\
\hline Baseline & $34.4(1.7)$ & $35.6(1.2)$ & $38.5(1.8)$ & $34.2(1.2)$ & & \\
\hline 6 months & $35.0(0.9)$ & $35.0(0.6)$ & $32.1(1.0)$ & $32.8(0.5)$ & $\begin{array}{c}(-6.0,0.2)^{\wedge} \\
\{ \pm 3.1\}\end{array}$ & $\begin{array}{c}(-3.8,-0.5)^{*} \\
\{ \pm 1.7\} \\
\end{array}$ \\
\hline \multicolumn{7}{|l|}{ Body fat, kg } \\
\hline Baseline & $38.8(2.2)$ & $42.8(2.4)$ & $38.9(2.4)$ & $42.6(2.4)$ & & \\
\hline 6 months & $38.9(1.7)$ & $44.3(1.6)$ & $34.3(1.9)$ & $37.5(1.5)$ & $\begin{array}{c}(-9.9,0.7)^{\wedge} \\
\{ \pm 5.3\}\end{array}$ & $\begin{array}{c}(-11.4,-2.2)^{*} \\
\{ \pm 4.6\}\end{array}$ \\
\hline \multicolumn{7}{|l|}{ Body fat (\%) } \\
\hline Baseline & $34.6(1.3)$ & $45.7(1.0)$ & $34.1(1.5)$ & $45.5(0.9)$ & & \\
\hline 6 months & $34.0(1.0)$ & $45.7(0.6)$ & $32.1(1.1)$ & $42.6(0.6)$ & $\begin{array}{c}(-5.2,1.4) \\
\{ \pm 3.3\}\end{array}$ & $\begin{array}{c}(-4.9,-1.2)^{*} \\
\{ \pm 1.9\}\end{array}$ \\
\hline \multicolumn{7}{|l|}{ Trunk fat, $\mathrm{kg}$} \\
\hline Baseline & $20.7(1.3)$ & $20.5(1.1)$ & $23.4(1.5)$ & $19.7(1.0)$ & & \\
\hline 6 months & $21.3(1.2)$ & $20.2(0.6)$ & $18.8(1.4)$ & $17.8(0.6)$ & $\begin{array}{c}(-6.8,1.6) \\
\{ \pm 4.2\}\end{array}$ & $\begin{array}{c}(-4.2,-0.7)^{*} \\
\{ \pm 1.8\}\end{array}$ \\
\hline \multicolumn{7}{|l|}{ Fat free mass, $\mathrm{kg}$} \\
\hline Baseline & $73.0(2.5)$ & $52.1(1.7)$ & $70.4(2.8)$ & $49.5(1.6)$ & & \\
\hline 6 months & $74.3(0.9)$ & $51.1(0.6)$ & $69.7(1.1)$ & $50.0(0.6)$ & $\begin{array}{c}(-7.7,-1.4)^{*} \\
\{ \pm 3.2\}\end{array}$ & $\begin{array}{c}(-2.9,0.6) \\
\{ \pm 1.8\}\end{array}$ \\
\hline \multicolumn{7}{|l|}{ Step counts, $n$} \\
\hline Baseline & 4720 (649) & $5065(790)$ & $3339(723)$ & $3555(727)$ & & \\
\hline 6 months & $4719(715)$ & $4676(1030)$ & $7698(801)$ & $7101(769)$ & $\begin{array}{c}(535,5421)^{*} \\
\{ \pm 2443\}\end{array}$ & $\begin{array}{c}(-555,5405) \\
\{ \pm 2980\}\end{array}$ \\
\hline \multicolumn{7}{|l|}{ Energy intake, kcals } \\
\hline Baseline & $2050.4(168)$ & $1881(150)$ & 1917 (197) & $1561(139)$ & & \\
\hline 6 months & $2088(120)$ & $1641(125)$ & $1489(141)$ & $1431(115)$ & $\begin{array}{c}(-1012,-186)^{*} \\
\{ \pm 413\}\end{array}$ & $\begin{array}{c}(-584,164) \\
\{ \pm 374\}\end{array}$ \\
\hline \multicolumn{7}{|l|}{ Fat intake, $\%$ kcals } \\
\hline Baseline & $35.7(2.0)$ & $38.4(2.2)$ & $33.7(2.4)$ & $35.4(2.0)$ & & \\
\hline 6 Months & $36.9(2.5)$ & $35.6(1.3)$ & $34.6(2.9)$ & $27.7(1.2)$ & $\begin{array}{c}(-20.9,-3.7)^{*} \\
\{ \pm 8.6\}\end{array}$ & $\begin{array}{c}(-11.6,-4.2)^{*} \\
\{ \pm 3.7\}\end{array}$ \\
\hline
\end{tabular}


Table 2: Continued.

\begin{tabular}{|c|c|c|c|c|c|c|}
\hline \multirow{2}{*}{ Variable } & \multicolumn{2}{|c|}{ Weight stable } & \multicolumn{2}{|c|}{ Weight loss } & \multicolumn{2}{|c|}{$\begin{array}{c}95 \% \text { confidence interval } \\
\{\text { cutoff for } 50 \% \text { power }\} \\
\text { for mean difference } \\
(\mathrm{WL}-\mathrm{WS}) \text { at } 6 \text { Month }\end{array}$} \\
\hline & $\begin{array}{c}\text { Men } \\
(n=12)\end{array}$ & $\begin{array}{l}\text { Women } \\
(n=13)\end{array}$ & $\begin{array}{c}\text { Men } \\
(n=12)\end{array}$ & $\begin{array}{l}\text { Women } \\
(n=14)\end{array}$ & Men & Women \\
\hline \multicolumn{7}{|c|}{ Carbohydrate intake, $\%$ kcals } \\
\hline Baseline & $48.8(2.7)$ & $48.0(2.6)$ & $47.3(3.2)$ & $50.8(2.4)$ & \multirow[b]{2}{*}{$\begin{array}{c}(2.4,22.0)^{*} \\
\{ \pm 9.8\}\end{array}$} & \multirow[b]{2}{*}{$\begin{array}{c}(1.7,13.3)^{*} \\
\{ \pm 5.8\}\end{array}$} \\
\hline 6 months & $47.3(2.9)$ & $50.1(2.0)$ & $59.5(3.4)$ & $57.6(1.8)$ & & \\
\hline \multicolumn{7}{|c|}{ Protein intake, $\%$ kcals } \\
\hline Baseline & $15.0(1.1)$ & $15.7(0.7)$ & $18.1(1.3)$ & $16.2(0.7)$ & \multirow[b]{2}{*}{$\begin{array}{c}(-0.4,6.8)^{\wedge} \\
\{ \pm 3.6\}\end{array}$} & \multirow[b]{2}{*}{$\begin{array}{c}(-1.3,5.0) \\
\{ \pm 3.2\}\end{array}$} \\
\hline 6 months & $15.4(1.0)$ & $16.6(1.1)$ & $18.6(1.2)$ & $18.4(1.0)$ & & \\
\hline
\end{tabular}

the participants were female (53\%) and Caucasian (88\%); mean age was $69.3 \pm 0.9$ years (range 60 to 84 years). Initial weight and BMI for the active cohort were $101.2 \mathrm{~kg}$ and $35.0 \mathrm{~kg} / \mathrm{m}^{2}$. Additionally, there were no differences in physical fitness among the groups at baseline as indicated by maximal work capacity.

A major goal of this study was to develop a successful intensive weight loss intervention in older obese adults that incorporated meal replacements and exercise training. The aim of this analysis was to explore the effect of the weight loss intervention on biomarkers. Compliance with the WL intervention for the 26 participants was measured by attendance to the weekly nutrition classes ( mean $=74.0 \%$; $\sim 20$ of 26 classes attended) and exercise training classes ( mean $=76.3 \% ; \sim 50$ out of 66 sessions attended). Table 2 shows measures for groups at baseline and 6 months for body weight and composition outcomes and behaviors associated with the interventions (step counts and dietary intake). Analyses of covariance between groups on 6 month measures were adjusted for covariates of age, race, and respective baseline measure. The WL groups showed weight change of $-13.0 \pm 2.3 \%$ and $-6.7 \pm 1.6 \%$ relative to initial body weight for men and women, respectively, which is greater than the $-1.0 \pm 2.1 \%$ and $0.6 \pm 1.6 \%$ change in the WS men and women, respectively. Additionally, women in the WL had reduced amounts of three measures of body fat at 6 months compared to the WS group. Men also had trends for reduction in BMI $(P=0.062 ; 95 \%$ confidence interval for mean difference is $-6.02,0.17)$ and body fat $(P=0.087 ; 95 \%$ confidence interval for mean difference is $-9.91,0.74)$. Also, men showed reduced levels of fat-free mass at 6 months for WL versus WS, which was not apparent in women. For the lifestyle behaviors, men in WL showed an increase in step counts, a reduction in energy intake and fat intake (\% of total kcals), an increase in carbohydrate intake (\% of total kcals), and a trend for increase in protein intake $(P=0.078$; $95 \%$ confidence interval for mean difference is -0.40 and
6.79). Although women showed similar patterns in diet and physical activity behaviors for comparisons between WL versus WS at 6 months, these only reached statistical significance for a reduction in dietary fat and an increase in dietary carbohydrate.

To present useful additional detail to the above tests, we present all of the corresponding 95\% confidence intervals for the mean group differences. Note that there is a significant difference (at critical $P$ value of 0.050 ) when the corresponding $95 \%$ confidence interval does not overlap 0.0 . Since the power of a $t$-test is 0.500 (i.e., $50 \%$ ) when the absolute value of the true population mean value equals the half width of the $95 \%$ confidence interval, we also derive and present, in braces, the cutoff true mean differences which would have had $50 \%$ power for our study. True mean differences that are less extreme (smaller in absolute value) would have smaller power, while more extreme differences would have larger power.

Few studies have examined how adipokines can be altered by a dietary restriction and exercise training intensive weight loss program in obese older men and women. Since leptin levels are linked to fat mass and to signaling the brain to reduce food consumption, understanding how these change during weight loss can provide insight into metabolic changes associated with weight loss. Plasma levels of leptin and its soluble receptor, and adiponectin, along with calculations among these to obtain free leptin index and ratios between leptin and adiponectin, and leptin and body fat mass were quantified at baseline and follow-up visits as shown in Table 3. Again, due to expected gender differences, these are presented for men and women separately. Because these values were not normally distributed, the log of the baseline and 6 month concentrations of each adipokine were obtained and used in the analysis. Both the log and nontransformed values are presented in the table for clarity. Surprisingly, the only significant effect of the intervention on these measures and calculations was for a lower leptin: adiponectin ratio in 
TABle 3: Plasma concentrations of adipokines at baseline and 6 months. Statistical analysis was performed on 6 months log values. These means are estimated marginal means (SEM). Nontransformed values are presented for ease of reference.

\begin{tabular}{|c|c|c|c|c|c|c|}
\hline & \multicolumn{2}{|c|}{ Weight stable } & \multicolumn{2}{|c|}{ Weight loss } & \multicolumn{2}{|c|}{$\begin{array}{l}\text { 95\% confidence interval } \\
\text { \{cutoff for } 50 \% \text { power } \\
\text { for mean difference } \\
(\mathrm{WL}-\mathrm{WS} \text { ) at } 6 \text { months }\end{array}$} \\
\hline & $\begin{array}{c}\text { Men } \\
(n=12)\end{array}$ & $\begin{array}{l}\text { Women } \\
(n=13)\end{array}$ & $\begin{array}{c}\text { Men } \\
(n=12)\end{array}$ & $\begin{array}{l}\text { Women } \\
(n=14)\end{array}$ & Men & Women \\
\hline \multicolumn{7}{|c|}{ Log leptin, ng/mL } \\
\hline Baseline & $1.53(0.08)$ & $1.87(0.08)$ & $1.37(0.09)$ & $1.81(0.08)$ & \multirow{5}{*}{$\begin{array}{c}(-0.37,0.20) \\
\{ \pm 0.29\}\end{array}$} & \multirow{5}{*}{$\begin{array}{c}(-0.31,0.02)^{\wedge} \\
\{ \pm 0.17\}\end{array}$} \\
\hline 6 months & $1.37(0.09)$ & $1.88(0.06)$ & $1.30(0.10)$ & $1.74(0.05)$ & & \\
\hline \multicolumn{5}{|l|}{ Leptin, ng/mL } & & \\
\hline Baseline & $39.72(7.33)$ & $86.53(12.86)$ & $26.54(3.64)$ & $77.16(12.17)$ & & \\
\hline 6 months & $34.86(7.16)$ & $91.80(12.71)$ & $19.10(2.14)$ & $63.90(12.69)$ & & \\
\hline Log soluble le & & & & & \multirow{6}{*}{$\begin{array}{c}(-0.06,0.25) \\
\{ \pm 0.16\}\end{array}$} & \multirow{6}{*}{$\begin{array}{c}(-0.14,0.05) \\
\{ \pm 0.10\}\end{array}$} \\
\hline Baseline & $1.35(0.02)$ & $1.47(0.04)$ & $1.34(0.02)$ & $1.43(0.04)$ & & \\
\hline 6 months & $1.31(0.05)$ & $1.53(0.03)$ & $1.40(0.06)$ & $1.49(0.03)$ & & \\
\hline \multicolumn{5}{|c|}{ Soluble leptin receptor, $\mathrm{ng} / \mathrm{mL}$} & & \\
\hline Baseline & $22.70(1.02)$ & $30.44(3.41)$ & $22.10(0.71)$ & $28.68(2.27)$ & & \\
\hline 6 months & $21.99(1.86)$ & $35.04(2.68)$ & $24.82(1.36)$ & $31.01(2.08)$ & & \\
\hline Log adiponec & & & & & \multirow{6}{*}{$\begin{array}{c}(-0.10,0.14) \\
\{ \pm 0.12\}\end{array}$} & \multirow{6}{*}{$\begin{array}{c}(-0.03,0.29) \\
\{ \pm 0.16\}\end{array}$} \\
\hline Baseline & $3.99(0.06)$ & $4.15(0.06)$ & $4.05(0.07)$ & $4.17(0.05)$ & & \\
\hline 6 months & $4.02(0.04)$ & $4.12(0.05)$ & $4.04(0.04)$ & $4.25(0.05)$ & & \\
\hline \multicolumn{5}{|c|}{ Adiponectin, mg/mL } & & \\
\hline Baseline & $11.41(1.66)$ & $15.08(2.12)$ & $12.13(1.61)$ & $16.60(1.87)$ & & \\
\hline 6 months & $11.52(1.51)$ & $14.82(1.67)$ & $13.13(1.90)$ & $18.06(1.70)$ & & \\
\hline Log-free lepti & & & & & \multirow{6}{*}{$\begin{array}{c}(-0.53,0.22) \\
\{ \pm 0.38\}\end{array}$} & \multirow{6}{*}{$\begin{array}{c}(-0.29,0.04) \\
\{ \pm 0.17\}\end{array}$} \\
\hline Baseline & $2.18(0.09)$ & $2.41(0.10)$ & $2.02(0.10)$ & $2.38(0.10)$ & & \\
\hline 6 months & $2.06(0.12)$ & $2.37(0.06)$ & $1.90(0.13)$ & $2.24(0.05)$ & & \\
\hline \multicolumn{5}{|c|}{ Free leptin index } & & \\
\hline Baseline & $177.26(33.67)$ & $349.62(75.91)$ & $125.74(18.89)$ & $294.41(51.15)$ & & \\
\hline 6 months & $276.27(150.28)$ & $272.86(36.60)$ & $76.45(6.65)$ & $213.85(42.74)$ & & \\
\hline \multicolumn{5}{|c|}{ Log leptin : adiponectin ratio } & \multirow{6}{*}{$\begin{array}{c}(-0.44,0.17) \\
\quad\{ \pm 0.31\}\end{array}$} & \multirow{6}{*}{$\begin{array}{c}(-0.54,-0.05)^{*} \\
\{ \pm 0.25\}\end{array}$} \\
\hline Baseline & $0.54(0.11)$ & $0.73(0.10)$ & $0.32(0.12)$ & $0.65(0.10)$ & & \\
\hline 6 months & $0.37(0.09)$ & $0.78(0.08)$ & $0.24(0.10)$ & $0.48(0.08)$ & & \\
\hline \multicolumn{5}{|c|}{ Leptin : adiponectin ratio } & & \\
\hline Baseline & $4.12(0.74)$ & $7.53(1.76)$ & $2.82(0.51)$ & $5.42(0.96)$ & & \\
\hline 6 months & $3.38(0.64)$ & $6.73(0.91)$ & $1.78(0.30)$ & $4.23(1.05)$ & & \\
\hline
\end{tabular}


TABle 3: Continued.

\begin{tabular}{|c|c|c|c|c|c|c|}
\hline & \multicolumn{2}{|c|}{ Weight stable } & \multicolumn{2}{|c|}{ Weight loss } & \multicolumn{2}{|c|}{$\begin{array}{l}95 \% \text { confidence interval } \\
\text { \{cutoff for } 50 \% \text { power }\} \\
\text { for mean difference } \\
(\mathrm{WL}-\mathrm{WS} \text { ) at } 6 \text { months }\end{array}$} \\
\hline & $\begin{array}{c}\text { Men } \\
(n=12)\end{array}$ & $\begin{array}{l}\text { Women } \\
(n=13)\end{array}$ & $\begin{array}{c}\text { Men } \\
(n=12)\end{array}$ & $\begin{array}{l}\text { Women } \\
(n=14)\end{array}$ & Men & Women \\
\hline \multicolumn{7}{|c|}{ Log leptin/kg body fat } \\
\hline Baseline & $-0.02(0.07)$ & $0.25(0.08)$ & $-0.28(0.08)$ & $0.18(0.08)$ & & \\
\hline 6 months & $-0.16(0.10)$ & $0.24(0.04)$ & $-0.30(0.12)$ & $0.21(0.04)$ & $\begin{array}{c}(-0.50,0.21) \\
\{ \pm 0.36\}\end{array}$ & $\begin{array}{c}(-0.16,0.09) \\
\{ \pm 0.13\}\end{array}$ \\
\hline \multicolumn{7}{|c|}{ Leptin/kg body fat } \\
\hline Baseline & $0.97(0.13)$ & $2.06(0.30)$ & $0.69(0.10)$ & $1.77(0.28)$ & & \\
\hline 6 months & $0.83(0.14)$ & $2.12(0.29)$ & $0.62(0.07)$ & $1.57(0.20)$ & & \\
\hline
\end{tabular}

Free leptin index $=$ (leptin : soluble leptin receptor $) \times 100$.

* Indicates $P<0.050$ for comparison between groups within gender. (Note that $P<0.050$ corresponds to the associated difference confidence interval not overlapping 0.00.)

${ }^{\wedge}$ Indicates $P \geq 0.050$ to $<0.100$ for comparison between groups within gender.

The power is $50 \%$ if the absolute value of the true mean difference equals the half width of the respective $95 \%$ confidence interval.

women for WL versus WS at 6 months $(P=0.021 ; 95 \%$ confidence interval for mean (WL - WS) difference: -0.54 and -0.05). However, there was a trend for leptin to be lower for WL versus WS in women $(P=0.081 ; 95 \%$ confidence interval for mean difference: -0.31 and 0.02$)$. Note that the power is $50 \%$ for the above two tests at true population mean differences of $\pm(0.49 / 2)$ and $\pm(0.33 / 2)$, respectively.

One striking difference in this table is in the levels of leptin between the men and the women. In younger individuals, the higher levels of leptin in females than males, even when matched for BMI, have been reported, so we asked if these differences are still present in older and obese individuals. To highlight this difference, the leptin levels in these groups are shown in Figure 1. This data set indicates that there are 2- to 3-fold higher levels of leptin in women, than in men, in older obese adults; these gender differences are statistically significant based on an independent twosample $t$-test. The trend for leptin decreasing in women is also noted on this graph.

Examination of partial correlations between the 6 month adipokines' levels after adjustment for background, gender, group, and age suggests some potential causal influences between the adipokines. For men of the WS group, the partial correlation between leptin and soluble leptin receptor was $r=-0.461(P=0.251)$, between leptin and adiponectin was $r=0.273(P=0.512)$, and between soluble leptin receptor and adiponectin was $r=0.557(P=0.152)$. For women of the WS group the partial correlations are for the leptin and soluble leptin receptor $(r=0.587, P=0.126)$, for leptin and adiponectin $(r=0.296, P=0.476)$, and for soluble leptin receptor and adiponectin $(r=-0.083, P=0.845)$. For men of the WL group, the partial correlations are the following: leptin and soluble leptin receptor $(r=0.155, P=0.691)$, leptin and adiponectin $(r=0.333, P=0.381)$, and soluble leptin receptor and adiponectin $(r=-0.064, P=0.871)$. For women of the WL group the partial correlations for the adipokine pairs are: leptin and soluble leptin receptor

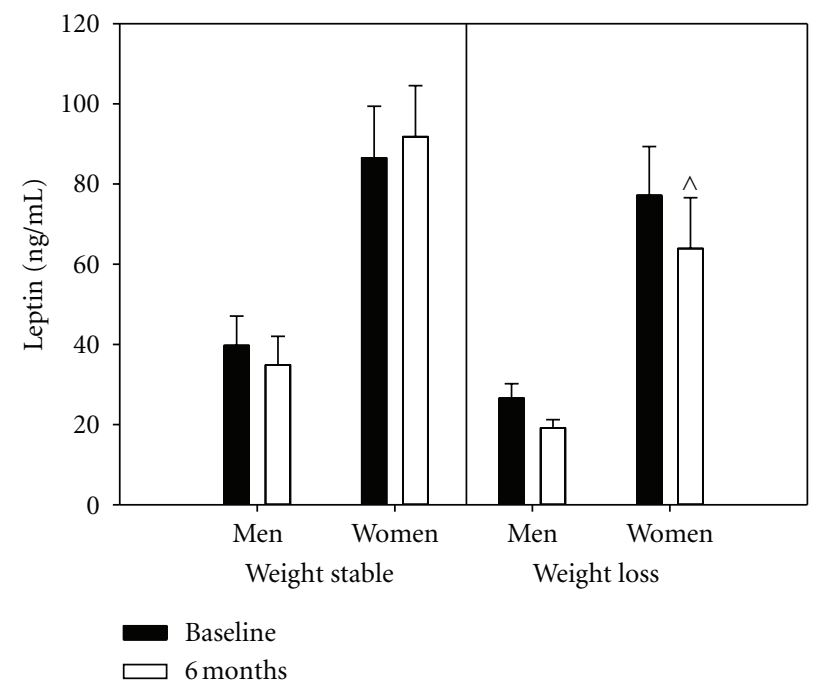

FIGURE 1: Group comparisons of leptin concentrations at baseline and 6 months for women and men. $\wedge$ Represents significant differences between WS and WL for women at the 6 months at $P<0.100$. Bars present sample means augmented with their standard errors. All versus women mean differences are statistically significant with group and sample time combinations.

$(r=0.316, P=0.374)$; leptin and adiponectin $(r=-0.457$, $P=0.184)$ and soluble leptin receptor and adiponectin $(r=$ $-0.047, P=0.898)$. It is interesting that there were trends of gender and group differences in these partial correlations.

Spearman correlations were performed to look at associations between measures of body composition, fitness, physical activity, and dietary intake with the adipokines, separately by gender (Table 4 for men and Table 5 for women). For both men and women, the strongest correlations were seen for leptin with percent body fat at baseline and 6 months. Furthermore, percent body fat was significantly correlated 
TABLE 4: Spearman correlations at baseline and 6 months for men between adipokines and body fat \%, trunk fat, step counts, dietary intake, and peak METS from GXT (baseline only). Data are presented as rho correlation coefficient ( $P$ value).

\begin{tabular}{|c|c|c|c|c|c|}
\hline & Leptin & Soluble leptin receptor & Adiponectin & Free leptin Index & Leptin : adiponectin \\
\hline \multicolumn{6}{|l|}{ Body fat (\%) } \\
\hline Baseline & $0.695(P<0.001)^{*}$ & $0.128(P=0.559)$ & $0.401(P=0.058)^{\wedge}$ & $0.570(P=0.005)^{*}$ & $0.133(P=0.544)$ \\
\hline 6 months & $0.465(0.026)^{*}$ & $0.007(0.973)$ & $0.220(0.312)$ & $0.441(0.035)^{*}$ & $0.233(0.284)$ \\
\hline \multicolumn{6}{|l|}{ Trunk fat } \\
\hline Baseline & $0.183(0.404)$ & $0.367(P=0.085)^{\wedge}$ & $0.518(P=0.011)^{*}$ & $0.056(P=0.799)$ & $-0.150(P=0.494)$ \\
\hline 6 months & $0.222(0.321)$ & $0.091(0.687)$ & $-0.005(0.982)$ & $0.186(0.408)$ & $0.313(0.156)$ \\
\hline \multicolumn{6}{|l|}{ METS } \\
\hline Baseline & $-0.192(P=0.369)$ & $-0.059(P=0.784)$ & $-0.095(P=0.659)$ & $-0.112(P=0.601)$ & $-0.002(P=0.994)$ \\
\hline 6 months & $\#$ & $\#$ & $\#$ & \# & \# \\
\hline \multicolumn{6}{|l|}{ Step counts } \\
\hline Baseline & $-0.134(P=0.553)$ & $-0.099(0.662)$ & $-0.051(0.820)$ & $-0.028(0.903)$ & $-0.006(0.978)$ \\
\hline 6 months & $-0.168(0.444)$ & $0.141(0.520)$ & $0.005(0.982)$ & $-0.190(0.386)$ & $-0.299(0.165)$ \\
\hline \multicolumn{6}{|l|}{ Energy intake } \\
\hline Baseline & $-0.237(0.276)$ & $0.310(0.150)$ & $0.174(0.427)$ & $-0.298(0.167)$ & $-0.006(0.978)$ \\
\hline 6 months & $0.230(0.291)$ & $-0.042(0.847)$ & $0.351(0.101)$ & $0.216(0.321)$ & $-0.024(0.914)$ \\
\hline \multicolumn{6}{|c|}{ Fat intake $(\%)$} \\
\hline Baseline & $0.158(0.471)$ & $0.105(0.634)$ & $0.325(0.130)$ & $0.154(0.483)$ & $-0.113(0.609)$ \\
\hline 6 months & $0.191(0.383)$ & $-0.135(0.538)$ & $0.315(0.143)$ & $0.217(0.319)$ & $-0.125(0.571)$ \\
\hline \multicolumn{6}{|c|}{ Carbohydrate intake (\%) } \\
\hline Baseline & $0.042(0.847)$ & $-0.445(0.034)^{*}$ & $-0.299(0.165)$ & $0.093(0.673)$ & $0.267(0.218)$ \\
\hline 6 months & $-0.118(0.593)$ & $-0.161(0.463)$ & $-0.243(0.264)$ & $-0.085(0.700)$ & $0.112(0.612)$ \\
\hline \multicolumn{6}{|c|}{ Protein intake $(\%)$} \\
\hline Baseline & $-0.242(0.266)$ & $-0.047(0.830)$ & $-0.263(0.266)$ & $-0.226(0.299)$ & $-0.119(0.590)$ \\
\hline 6 months & $-0.351(0.101)$ & $0.113(0.609)$ & $-0.063(0.774)$ & $0.379(0.074)^{\wedge}$ & $-0.249(0.252)$ \\
\hline
\end{tabular}

* Indicates statistical significance at $P<0.05 ; \wedge$ indicates $P$ value $\geq 0.050$ and $<0.100$.

"Indicates that comparisons were only from baseline measures of METS.

with free leptin index; also, percent body fat showed a trend towards significance with adiponectin at baseline $(P=$ 0.058). The only other significant findings or trends towards significant correlations for men were between carbohydrate intake and soluble leptin receptor at baseline and protein intake for free leptin index (6 months only). For women, in addition to leptin, percent body fat also showed significance or trends towards significance for soluble leptin receptor $(r=$ $0.347, P=0.076$ at 6 months $)$, free leptin index $(r=0.369$, $P=0.058$ at baseline; $r=0.631, P<0.001$ at 6 months), and leptin: adiponectin ratio $(r=0.333, P=0.089$ at baseline; $r=0.562, P=0.002$ at 6 months). Additionally, trunk fat, an index for visceral abdominal fat, was at 6 months correlated with leptin $(r=0.471, P=0.013)$, soluble leptin receptor $(r=0.368, P=0.059)$, free leptin index $(r=0.335$, $P=0.087)$, and leptin: adiponectin ratio $(r=0.454, P=$ 0.017 ). Women also showed a number of significant (and trends for significant) correlations between adipokines and step counts and intake of total calories and macronutrients. Step counts were negatively correlated at 6 months with leptin $(r=-0.464, P=0.034)$ and free leptin index $(r=$ $-0.408, P=0.067)$. Energy intake was associated with soluble leptin receptor at baseline $(r=0.411, P=0.037)$. Fat intake was associated with soluble leptin receptor at 6 months $(r=0.449, P=0.021)$. At baseline, carbohydrate intake was associated with leptin $(r=0.498, P=0.010)$, free leptin index $(r=0.413, P=0.036)$, and leptin : adiponectin ratio $(r=0.428, P=0.029)$. Finally, soluble leptin receptor was negatively correlated with protein intake at both baseline $(r=-0.342, P=0.088)$ and 6 months $(r=-0.393$, $P=0.047)$.

Interestingly, the gender differences in adipokines were apparent when the percentage changes from baseline to 6 months were examined. The relationship between the percent change in adipokine levels and differences in \% body fat, trunk fat, and step counts is shown in Table 6. In the women, the change in leptin, the free leptin index, and the leptin: adiponectin ratio were also significantly correlated with the change in percent body fat $(r=0.590, P=0.001$ for leptin; $r=0.431, P=0.025$ for free leptin index; $r=0.430, P=$ 0.025 for leptin: adiponectin) and trunk fat $(r=0.540, P=$ 0.004 for leptin, $r=0.386, P=0.047$ for free leptin index; $r=0.422, P=0.028$ for leptin: adiponectin). In men, the only significant relationships were between changes in the free leptin index and the leptin: adiponectin ratio with the change in step counts $(r=-0.425, P=0.049$ for free leptin index; $r=-0.530, P=0.011$ for leptin : adiponectin).

\section{Discussion}

The goal of this analysis was to assess the effect of the lifestyle behavioral weight loss intervention on adipokine levels in 
TABle 5: Spearman correlations at baseline and 6 months for women between adipokines and body fat \%, trunk fat, step counts, dietary intake, and peak METS from GXT (baseline only). Data are presented as rho correlation coefficient ( $P$ value).

\begin{tabular}{|c|c|c|c|c|c|}
\hline & Leptin & Soluble leptin receptor & Adiponectin & Free leptin index & Leptin : adiponectin \\
\hline \multicolumn{6}{|l|}{ Body fat (\%) } \\
\hline Baseline & $0.440(0.022)^{*}$ & $-0.090(0.656)$ & $0.015(0.940)$ & $0.369(0.058)^{\wedge}$ & $0.333(0.089)^{\wedge}$ \\
\hline 6 months & $0.757(P<0.001)^{*}$ & $0.347(0.076)^{\wedge}$ & $-0.067(0.739)$ & $0.631(P<0.001)^{*}$ & $0.562(0.002)^{*}$ \\
\hline \multicolumn{6}{|l|}{ Trunk fat } \\
\hline Baseline & $0.099(0.624)$ & $0.226(0.256)$ & $0.136(0.498)$ & $0.046(0.821)$ & $0.018(0.928)$ \\
\hline 6 months & $0.471(0.013)^{*}$ & $0.368(0.059)^{\wedge}$ & $-0.167(0.406)$ & $0.335(0.087)^{\wedge}$ & $0.454(0.017)^{*}$ \\
\hline \multicolumn{6}{|l|}{ METS } \\
\hline Baseline & $-0.276(0.172)$ & $-0.091(0.657)$ & $-0.026(0.900)$ & $-0.198(0.333)$ & $-0.193(0.344)$ \\
\hline 6 months & \# & \# & \# & \# & \# \\
\hline \multicolumn{6}{|l|}{ Step counts } \\
\hline Baseline & $-0.054(0.792)$ & $0.157(0.444)$ & $0.172(0.401)$ & $-0.147(0.475)$ & $-0.085(0.679)$ \\
\hline 6 months & $-0.464(0.034)^{*}$ & $0.022(0.924)$ & $0.261(0.253)$ & $-0.408(0.067)^{\wedge}$ & $-0.349(0.121)$ \\
\hline \multicolumn{6}{|l|}{ Energy intake } \\
\hline Baseline & $-0.050(0.807)$ & $0.411(0.037)^{*}$ & $0.213(0.296)$ & $-0.156(0.446)$ & $-0.161(0.432)$ \\
\hline 6 months & $-0.121(0.555)$ & $0.320(0.111)$ & $-0.065(0.751)$ & $-0.206(0.312)$ & $0.006(0.978)$ \\
\hline \multicolumn{6}{|l|}{ Fat intake (\%) } \\
\hline Baseline & $-0.246(0.225)$ & $0.198(0.332)$ & $-0.062(0.764)$ & $-0.209(0.306)$ & $-0.226(0.267)$ \\
\hline 6 months & $0.032(0.875)$ & $0.449(0.021)^{*}$ & $0.105(0.610)$ & $-0.115(0.575)$ & $-0.033(0.872)$ \\
\hline \multicolumn{6}{|c|}{ Carbohydrate intake (\%) } \\
\hline Baseline & $0.498(0.010)^{*}$ & $-0.221(0.278)$ & $-0.048(0.815)$ & $0.413(0.036)^{*}$ & $0.428(0.029)^{*}$ \\
\hline 6 months & $-0.087(0.672)$ & $-0.160(0.434)$ & $-0.136(0.506)$ & $-0.030(0.883)$ & $0.069(0.739)$ \\
\hline \multicolumn{6}{|c|}{ Protein intake (\%) } \\
\hline Baseline & $-0.269(0.184)$ & $-0.342(0.088)^{\wedge}$ & $0.212(0.298)$ & $-0.056(0.787)$ & $-0.265(0.191)$ \\
\hline 6 months & $0.148(0.470)$ & $-0.393(0.047)^{*}$ & $0.120(0.559)$ & $0.246(0.226)$ & $-0.035(0.864)$ \\
\hline
\end{tabular}

* Indicates statistical significance at $P<0.05$; ${ }^{\wedge}$ indicates $P$ value $\geq 0.050$ and $<0.100$.

\# Indicates that comparisons were only from baseline measures of METS.

TABLE 6: Spearman correlations by gender for percent change from baseline to 6 months in adipokines and body fat and step counts.

\begin{tabular}{lcccccc}
\hline & \multicolumn{2}{c}{$\% \Delta$ Body fat } & \multicolumn{2}{c}{$\% \Delta$ Trunk fat } & \multicolumn{2}{c}{$\% \Delta$ Step counts } \\
& Men & Women & Men & Women & Men & Women \\
\hline$\% \Delta$ Leptin & $0.064(0.784)$ & $0.590(0.001)^{*}$ & $-0.048(0.836)$ & $0.540(0.004)^{*}$ & $-0.344(0.137)$ & $-0.216(0.348)$ \\
$\% \Delta$ sLR & $0.345(0.107)$ & $0.083(0.681)$ & $0.258(0.246)$ & $0.148(0.462)$ & $0.273(0.219)$ & $0.074(0.750)$ \\
$\% \Delta$ Adiponectin & $0.018(0.936)$ & $-0.229(0.251)$ & $-0.239(0.284)$ & $-0.217(0.278)$ & $0.330(0.133)$ & $0.281(0.218)$ \\
$\% \Delta$ Free leptin index & $-0.110(0.618)$ & $0.431(0.025)^{*}$ & $-0.139(0.536)$ & $0.386(0.047)^{*}$ & $-0.425(0.049)^{*}$ & $-0.231(0.313)$ \\
$\% \Delta$ Leptin : adiponectin & $-0.120(0.587)$ & $0.430(0.025)^{*}$ & $0.022(0.923)$ & $0.422(0.028)^{*}$ & $-0.530(0.011)^{*}$ & $-0.200(0.385)$ \\
\hline
\end{tabular}

older obese men and women. We also examined relationships between the adipokines and obesity indices, physical activity, and dietary intake at baseline and the end of the 6 month intervention. The weight loss intervention led to among the largest levels of weight loss published from a randomized behavioral weight loss intervention trial in older adults [3234]. Accompanying the change in weight were significantly lower body fat and trunk fat for women in WL as compared to WS. Men in WL showed a trend $(P \geq 0.050$ and $<0.100)$ for having lower body fat than WS. Men in WL versus WS showed higher physical activity and lower energy intake with lower fat intake and higher carbohydrate intake. Women in WL had a lower fat intake and higher carbohydrate intake, but no differences in total energy intake or step counts were identified in comparison to WS.
This study is unique in that it is the first study that examined leptin, adiponectin, and soluble leptin receptor together in older obese adults before and after weight loss. This allowed an assessment of these adipokines partial correlations (adjusted for other factors), suggesting potential multivariate relationships. Additionally, these findings add to the literature by reporting on the relationships between the adipokines and lifestyle behaviors. While it was hypothesized that the adipokines would show significant effects from the intervention, it was surprising that while there was a trend for difference in leptin levels in women, the only statistically significant $(P<0.050)$ WL versus WS difference was seen in women for the leptin: adiponectin ratio. This study also highlights the substantially higher levels ( $>2$ fold elevation) of leptin in females than males, which is similar to that 
reported in younger adults [15, 35-37]. This was suggested to be attributed to women having higher adiposity levels overall $[35,37,38]$, but in our study population, even when leptin levels were adjusted for body fat, women still had greater than 2-fold elevated levels than men (Table 3). Leptin also remained significantly correlated with percent whole body fat and trunk fat at the end of the intervention for women, but not for men.

Earlier reports have shown reductions in leptin in older adults following a dietary restriction based weight loss program [14]. In the earlier work, dietary induced weight loss (with and without exercise training) of 5-6\% over 18 months showed a decrease in serum leptin as compared to nondieting groups. The reason for the greater effect in that study than in this dataset may be from the longer followup period (6 versus 18 months), although others have shown changes in leptin in $\leq 6$ months of weight loss $[13,39]$. For better understanding of the data, we detail all of the $95 \%$ confidence intervals for our mean differences in WL versus WS as well as the cutoff for $50 \%$ power (see Table 3 ). Larger sample sizes would have yielded larger power. Earlier work by Monzillo and coworkers showed a statistically significant reduction in leptin during weight loss, although they only showed a $14 \%$ decrease in serum leptin $(27.9 \pm 3$ before and $23.6 \pm 3 \mathrm{ng} / \mathrm{mL}$ after $6 \%$ weight loss) [13]. In more intensive weight losses, serum leptin concentrations decreased by $45 \%$ [39] and 22\% [40]. Study populations in these earlier works were much younger than this current sample, and they were all insulin resistant. Although we do not have a measure of insulin resistance for our cohort, the medical history indicates that about 1 in $5(\sim 20 \%)$ had type 2 diabetes, with the distribution of these individuals being similar between the 2 intervention groups. The other studies focused only on brief but more extreme dietary interventions while our study included a modest modification of dietary and lifestyle behaviors.

Adiponectin levels did not change over the 6 month study for either men or women, but the leptin: adiponectin ratio was significantly lower in the WL group for women at the end of the intervention period than in the WS women. The leptin: adiponectin ratio has been shown to be a possible indicator of the metabolic syndrome, atherosclerosis, and insulin resistance with higher ratios serving as a marker for these obesity comorbidities [41-43]. Therefore, the reduced leptin: adiponectin ratio in WL women suggests a reduced risk for these comorbidities. Consistent with this hypothesis, the leptin : adiponectin ratio was significantly correlated with percent body fat and trunk fat in women. The lack of change in adiponectin levels from the intervention and positive correlation with percent fat and trunk fat (in men) were unexpected as adiponectin has been shown to be inversely correlated with fat mass $[44,45]$.

The soluble leptin receptor is thought to bind circulating leptin, and it has been proposed to control leptin action in two opposing ways. This soluble receptor may alter the proportion of free leptin, thereby inhibiting leptin binding to membrane leptin receptors and decreasing leptin activity $[24,46]$ by protecting leptin from degradation or by blocking its activity $[5,8-10]$. In this study we find significant positive correlations between body fat and trunk fat with soluble leptin receptor and free leptin index. This differs from a report that soluble leptin receptor levels were inversely correlated with fat mass in young, healthy participants [15]. Also, levels of sLR have been reported to be higher in men than women [47].

In our current analysis, the free leptin index was correlated with percent body fat at baseline and at 6 months in both men and women and had an inverse correlation with step count at 6 months for women. The correlation with percent body fat is consistent with findings of a previous study on young, healthy individuals [15]. The inverse correlation with step counts suggests that increased physical activity leads to lower levels of unbound leptin in the blood or less leptin activity. This finding is of interest due to the comorbidities seen in obese, hyperleptinemic individuals [47]. More studies on sLR levels in older individuals with obesity are needed to clarify how this receptor is affected by diet and exercise in this particular population. Because of the conflicting hypotheses on the role of soluble receptor in leptin signaling, it is important to have a more thorough understanding of factors that alter soluble leptin receptors.

Because lifestyle habits are modifiable, their effects on adipokine secretion are a critical issue, especially in obese older adults. The links between adipokines and disease conditions are becoming evident, thus understanding factors that modify their levels may have an impact on disease morbidity and mortality. Furthermore, changes to diet and physical activity provide safe alternatives to pharmacologic interventions. In this study, dietary components and physical activity had limited statistically significant correlations in either men or women with baseline and 6 month measures of adipokines. Others have shown that sLR was positively associated with carbohydrate intake and negatively associated with fat intake and that the free leptin index showed opposite associations (positively from fat and negatively from carbohydrate intake) [15]. These findings would suggest that, in this cohort, dietary intake and physical activity play a minor role in the variability seen in adipokine levels. This supports our earlier work which showed that exercise training had no effect on plasma leptin following an 18-month weight loss intervention [14]. Another factor contributing to the variance in adipokines that have previously been reported are regarding race/ethnicity $[21,23]$. The small number of nonCaucasians in our study sample precluded us from looking at this variable, although we adjusted for it in our univariate analyses models.

The older obese adults in this study had symptomatic knee osteoarthritis, consistent with obesity being a primary risk factor for knee osteoarthritis. This has been proposed to be, at least partly, from the hyperleptinemia present in obesity as leptin and adiponectin are high in individuals with osteoarthritis versus weight-matched controls [31]. Thus, the potential effect of weight loss in this cohort on leptin is of interest as adipokines may be a critical mediator of obesityrelated osteoarthritis $[34,48,49]$. In this modified cohort, pain and function also improved in both men and women from the intervention. However, there were no correlations between the different adipokines and these outcomes. 
In summary, there have been relatively few randomized controlled weight loss trials in older obese adults. This study identifies an effective weight loss regime for this population and explored adipokines and their interactions with body fat measures, dietary components, and exercise levels at baseline and after a six month control or intensive weight-loss intervention period. While a number of studies have looked at younger populations, it is becoming apparent that those studies' findings may not be directly applicable to the older obese population as metabolic alterations with aging may impact adipokines metabolism. Additionally, the striking differences between men and women in this age group in adipokine levels and their relationship to weight loss suggest further complexities in understanding the linkage between adipokines and metabolism. Understanding the regulatory factors for these adipokines and their soluble receptors may have important physiological and therapeutic implications for obesity and related comorbidities.

\section{Abbreviations}

BMI: Body Mass Index

PACT: Physical Activity, Inflammation, and Body Composition Trial

WL: Weight loss

WS: Weight stable

OA: Osteoarthritis

GCRC: General Clinical Research Center

DXA: Dual energy X-ray absorptiometry

METS: Metabolic equivalents

NDS: Nutrition data system

sLR: Soluble leptin receptor

GXT: Graded exercise test.

\section{Authors' Contribution}

G. D. Miller designed, implemented, analyzed data, and wrote the paper. M. Z. Jenks analyzed and interpreted the data and wrote the paper. M. Vendela analyzed and interpreted the data. J. L. Norris analyzed and interpreted the data. G. K. Muday analyzed and interpreted the data and wrote the paper. G. D. Miller and M. Z Jenks served as lead authors for publication.

\section{Conflict of Interests}

The authors have no conflict of interests to disclose.

\section{Acknowledgments}

This work was carried out at Wake Forest University, Winston-Salem, NC, USA. The authors wish to acknowledge Pamela Moser for subject recruitment, intervention delivery, and study coordinator, Gretchen Heggerick for intervention delivery, and Tina Ellis for testing and intervention delivery; and the help of the Clinical Research Unit staff. This project was funded by SlimFast Nutrition Institute, Wake Forest University, Claude D. Pepper Older American Independence
Center (NIH Grant P30 AG21332), Wake Forest University Clinical Research Unit (NIH Grant M01-RR07122), and Wake Forest University Science Research Fund.

\section{References}

[1] K. M. Flegal, M. D. Carroll, B. K. Kit, and C. L. Ogden, "Prevalence of obesity and trends in the distribution of body mass index among US adults, 1999-2010," Journal of the American Medical Association, vol. 307, pp. 491-497, 2012.

[2] E. Zoico and R. Roubenoff, "The role of cytokines in regulating protein metabolism and muscle function," Nutrition Reviews, vol. 60, no. 2, pp. 39-51, 2002.

[3] N. Ouchi, J. L. Parker, J. J. Lugus, and K. Walsh, "Adipokines in inflammation and metabolic disease," Nature Reviews Immunology, vol. 11, no. 2, pp. 85-97, 2011.

[4] A. H. Berg and P. E. Scherer, "Adipose tissue, inflammation, and cardiovascular disease," Circulation Research, vol. 96, no. 9, pp. 939-949, 2005.

[5] A. Koerner, J. Kratzsch, and W. Kiess, "Adipocytokines: leptin-the classical, resistin-the controversical, adiponectin-the promising, and more to come," Best Practice \& Research Clinical Endocrinology \& Metabolism, vol. 19, no. 4, pp. 525-546, 2005.

[6] H. Waki and P. Tontonoz, "Endocrine functions of adipose tissue," Annual Review of Pathology, vol. 2, pp. 31-56, 2007.

[7] S. Galic, J. S. Oakhill, and G. R. Steinberg, "Adipose tissue as an endocrine organ," Molecular and Cellular Endocrinology, vol. 316, no. 2, pp. 129-139, 2010.

[8] M. H. Rokling-Andersen, J. E. Reseland, M. B. Veierød et al., "Effects of long-term exercise and diet intervention on plasma adipokine concentrations," American Journal of Clinical Nutrition, vol. 86, no. 5, pp. 1293-1301, 2007.

[9] J. L. Chan, S. Blüher, N. Yiannakouris, M. A. Suchard, J. Kratzsch, and C. S. Mantzoros, "Regulation of circulating soluble leptin receptor levels by gender, adiposity, sex steroids, and leptin observational and interventional studies in humans," Diabetes, vol. 51, no. 7, pp. 2105-2112, 2002.

[10] L. Huang, Z. Wang, and C. Li, "Modulation of circulating leptin levels by its soluble receptor," Journal of Biological Chemistry, vol. 276, no. 9, pp. 6343-6349, 2001.

[11] B. E. Wolfe, D. C. Jimerson, C. Orlova, and C. S. Mantzoros, "Effect of dieting on plasma leptin, soluble leptin receptor, adiponectin and resistin levels in healthy volunteers," Clinical Endocrinology, vol. 61, no. 3, pp. 332-338, 2004.

[12] S. M. Ata, U. Vaishnav, M. Puglisi et al., "Macronutrient composition and increased physical activity modulate plasma adipokines and appetite hormones during a weight loss intervention," Journal of Women's Health, vol. 19, no. 1, pp. 139$145,2010$.

[13] L. U. Monzillo, O. Hamdy, E. S. Horton et al., "Effect of lifestyle modification on adipokine levels in obese subjects with insulin resistance," Obesity Research, vol. 11, no. 9, pp. 10481054, 2003.

[14] G. D. Miller, B. J. Nicklas, C. C. Davis, W. T. Ambrosius, R. F. Loeser, and S. P. Messier, "Is serum leptin related to physical function and is it modifiable through weight loss and exercise in older adults with knee osteoarthritis?" International Journal of Obesity, vol. 28, no. 11, pp. 1383-1390, 2004.

[15] M. Yannakoulia, N. Yiannakouris, S. Blüher, A. L. Matalas, D. Klimis-Zacas, and C. S. Mantzoros, "Body fat mass and macronutrient intake in relation to circulating soluble leptin 
receptor, free leptin index, adiponectin, and resistin concentrations in healthy humans," Journal of Clinical Endocrinology and Metabolism, vol. 88, no. 4, pp. 1730-1736, 2003.

[16] C. M. Friedenreich, H. K. Neilson, C. G. Woolcott et al., "Changes in insulin resistance indicators, IGFs, and adipokines in a year-long trial of aerobic exercise in postmenopausal women," Endocrine-Related Cancer, vol. 18, no. 3, pp. 357-369, 2011.

[17] J. Jürimäe, T. Kums, and T. Jürimäe, "Plasma adiponectin concentration is associated with the average accelerometer daily steps counts in healthy elderly females," European Journal of Applied Physiology, vol. 109, no. 5, pp. 823-828, 2010.

[18] V. M. Mendoza-Núñez, Á. García-Sánchez, M. SánchezRodríguez, R. E. Galván-Duarte, and M. E. Fonseca-Yerena, "Overweight, waist circumference, age, gender, and insulin resistance as risk factors for hyperleptinemia," Obesity Research, vol. 10, no. 4, pp. 253-259, 2002.

[19] Y. M. Rolland, H. M. Perry, P. Patrick, W. A. Banks, and J. E. Morley, "Leptin and adiponectin levels in middle-aged postmenopausal women: associations with lifestyle habits, hormones, and inflammatory markers-a cross-sectional study," Metabolism, vol. 55, no. 12, pp. 1630-1636, 2006.

[20] C. E. Ruhl, J. E. Everhart, J. Ding et al., "Serum leptin concentrations and body adipose measures in older black and white adults," American Journal of Clinical Nutrition, vol. 80, no. 3, pp. 576-583, 2004.

[21] U. I. Khan, D. Wang, M. R. Sowers et al., "Race-ethnic differences in adipokine levels: the Study of Women's Health Across the Nation (SWAN)," Metabolism, vol. 61, pp. 12611269, 2012.

[22] B. J. Nicklas, "Gender differences in the response of plasma leptin concentrations to weight loss in obese older individuals," Obesity Research, vol. 5, no. 1, pp. 62-68, 1997.

[23] B. J. Nicklas, M. J. Toth, A. P. Goldberg, and E. T. Poehlman, "Racial differences in plasma leptin concentrations in obese postmenopausal women," Journal of Clinical Endocrinology and Metabolism, vol. 82, no. 1, pp. 315-317, 1997.

[24] J. Kratzsch, A. Lammert, A. Bottner et al., "Circulating soluble leptin receptor and free leptin index during childhood, puberty, and adolescence," Journal of Clinical Endocrinology and Metabolism, vol. 87, no. 10, pp. 4587-4594, 2002.

[25] N. Moller, P. O'Brien, and K. S. Nair, "Disruption of the relationship between fat content and leptin levels with aging in humans," Journal of Clinical Endocrinology and Metabolism, vol. 83, no. 3, pp. 931-934, 1998.

[26] R. F. Loeser, "Systemic and local regulation of articular cartilage metabolism: where does leptin fit in the puzzle?" Arthritis and Rheumatism, vol. 48, no. 11, pp. 3009-3012, 2003.

[27] Y. Figenschau, G. Knutsen, S. Shahazeydi, O. Johansen, and B. Sveinbjörnsson, "Human articular chondrocytes express functional leptin receptors," Biochemical and Biophysical Research Communications, vol. 287, no. 1, pp. 190-197, 2001.

[28] M. Otero, J. J. Gomez Reino, and O. Gualillo, "Synergistic induction of nitric oxide synthase type II: in vitro effect of leptin and interferon- $\gamma$ in human chondrocytes and ATDC5 chondrogenic cells," Arthritis and Rheumatism, vol. 48, no. 2, pp. 404-409, 2003.

[29] A. Scharstuhl, H. L. Glansbeek, H. M. Van Beuningen, E. L. Vitters, P. M. Van der Kraan, and W. B. Van den Berg, "Inhibition of endogenous TGF- $\beta$ during experimental osteoarthritis prevents osteophyte formation and impairs cartilage repair," Journal of Immunology, vol. 169, no. 1, pp. 507-514, 2002.
[30] R. I. Issa and T. M. Griffin, "Pathobiology of obesity and osteoarthritis: integrating biomechanics and inflammation," Pathobiology of Aging \& Age Related Diseases, vol. 2, Article ID 17470, 2012.

[31] T. N. de Boer, W. E. van Spil, A. M. Huisman et al., "Serum adipokines in osteoarthritis, comparison with controls and relationship with local parameters of synovial inflammation and cartilage damage," Osteoarthritis Cartilage, vol. 20, pp. 846-853, 2012.

[32] G. D. Miller, B. J. Nicklas, C. Davis, R. F. Loeser, L. Lenchik, and S. P. Messier, "Intensive weight loss program improves physical function in older obese adults with knee osteoarthritis," Obesity, vol. 14, no. 7, pp. 1219-1230, 2006.

[33] M. D. Witham and A. Avenell, "Interventions to achieve longterm weight loss in obese older people. A systematic review and meta-analysis," Age and Ageing, vol. 39, no. 2, pp. 176$184,2010$.

[34] G. D. Miller, B. J. Nicklas, and R. F. Loeser, "Inflammatory biomarkers and physical function in older, obese adults with knee pain and self-reported osteoarthritis after intensive weight-loss therapy," Journal of the American Geriatrics Society, vol. 56, no. 4, pp. 644-651, 2008.

[35] M. G. McConway, D. Johnson, A. Kelly, D. Griffin, J. Smith, and A. M. Wallace, "Differences in circulating concentrations of total, free and bound leptin relate to gender and body composition in adult humans," Annals of Clinical Biochemistry, vol. 37, no. 5, pp. 717-723, 2000.

[36] S. M. Kuo and M. M. Halpern, "Lack of association between body mass index and plasma adiponectin levels in healthy adults," International Journal of Obesity, vol. 35, pp. 14871494, 2011.

[37] P. Magni, A. Liuzzi, M. Ruscica et al., "Free and bound plasma leptin in normal weight and obese men and women: relationship with body composition, resting energy expenditure, insulin-sensitivity, lipid profile and macronutrient preference," Clinical Endocrinology, vol. 62, no. 2, pp. 189-196, 2005.

[38] M. Rosenbaum, M. Nicolson, J. Hirsch et al., "Effects of gender, body composition, and menopause on plasma concentrations of leptin," Journal of Clinical Endocrinology and Metabolism, vol. 81, no. 9, pp. 3424-3427, 1996.

[39] J. P. Bastard, C. Jardel, E. Bruckert et al., "Elevated levels of interleukin 6 are reduced in serum and subcutaneous adipose tissue of obese women after weight loss," Journal of Clinical Endocrinology and Metabolism, vol. 85, no. 9, pp. 3338-3342, 2000.

[40] C. Xenachis, E. Samojlik, M. P. Raghuwanshi, and M. A. Kirschner, "Leptin, insulin and TNF- $\alpha$ in weight loss," Journal of Endocrinological Investigation, vol. 24, no. 11, pp. 865-870, 2001.

[41] F. M. Finucane, J. Luan, N. J. Wareham et al., "Correlation of the leptin: adiponectin ratio with measures of insulin resistance in non-diabetic individuals," Diabetologia, vol. 52, no. 11, pp. 2345-2349, 2009.

[42] B. Thorand, A. Zierer, J. Baumert, C. Meisinger, C. Herder, and W. Koenig, "Associations between leptin and the leptin/adiponectin ratio and incident Type 2 diabetes in middleaged men and women: results from the MONICA/KORA Augsburg Study 1984-2002," Diabetic Medicine, vol. 27, no. 9, pp. 1004-1011, 2010.

[43] N. Satoh, M. Naruse, T. Usui et al., "Leptin-to-adiponectin ratio as a potential atherogenic index in obese type 2 diabetic patients," Diabetes Care, vol. 27, no. 10, pp. 2488-2490, 2004.

[44] Y. Arita, S. Kihara, N. Ouchi et al., "Paradoxical decrease of an adipose-specific protein, adiponectin, in obesity," Biochemical 
and Biophysical Research Communications, vol. 257, no. 1, pp. 79-83, 1999.

[45] K. Hotta, T. Funahashi, Y. Arita et al., "Plasma concentrations of a novel, adipose-specific protein, adiponectin, in type 2 diabetic patients," Arteriosclerosis, Thrombosis, and Vascular Biology, vol. 20, no. 6, pp. 1595-1599, 2000.

[46] A. Lammert, W. Kiess, A. Bottner, A. Glasow, and J. Kratzsch, "Soluble leptin receptor represents the main leptin binding activity in human blood," Biochemical and Biophysical Research Communications, vol. 283, no. 4, pp. 982-988, 2001.

[47] J. Beltowski, "Leptin and atherosclerosis," Atherosclerosis, vol. 189, no. 1, pp. 47-60, 2006.

[48] S. P. Messier, R. F. Loeser, M. N. Mitchell et al., "Exercise and weight loss in obese older adults with knee osteoarthritis: a preliminary study," Journal of the American Geriatrics Society, vol. 48, no. 9, pp. 1062-1072, 2000.

[49] S. P. Messier, R. F. Loeser, G. D. Miller et al., "Exercise and dietary weight loss in overweight and obese older adults with knee osteoarthritis: the arthritis, diet, and activity promotion trial," Arthritis and Rheumatism, vol. 50, no. 5, pp. 1501-1510, 2004. 


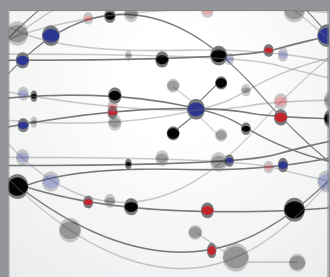

The Scientific World Journal
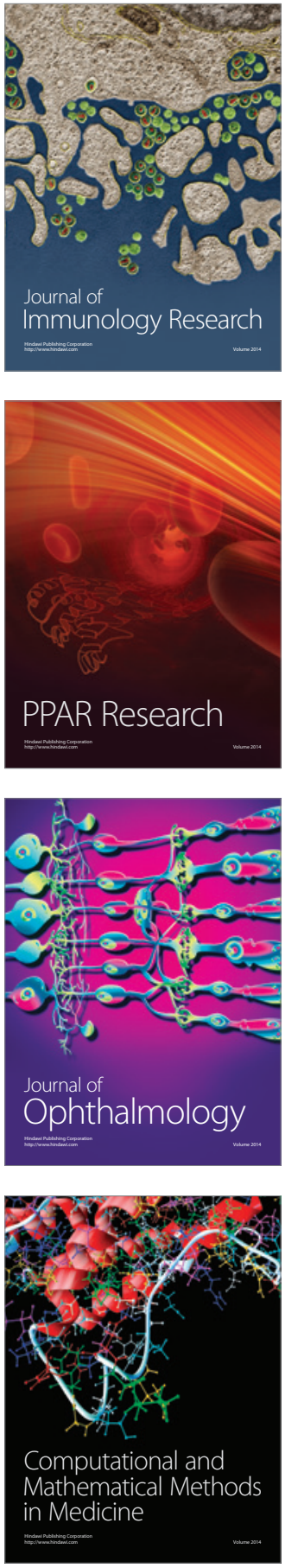

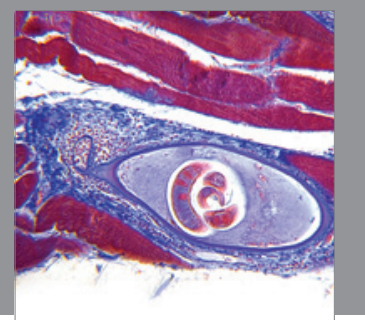

Gastroenterology

Research and Practice
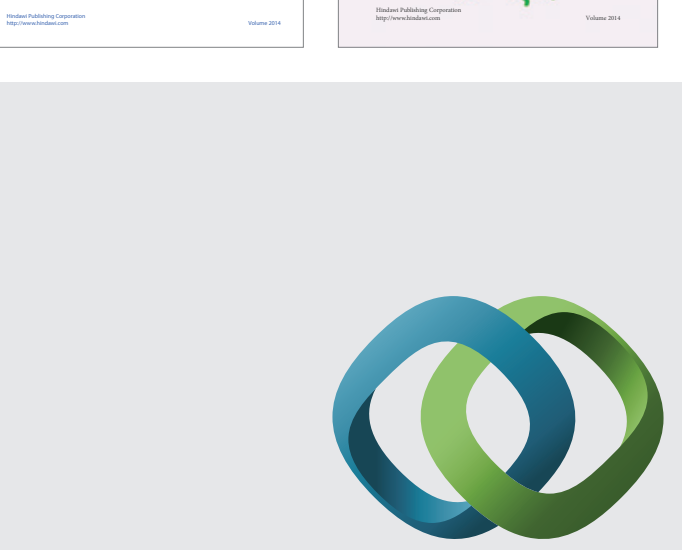

\section{Hindawi}

Submit your manuscripts at

http://www.hindawi.com
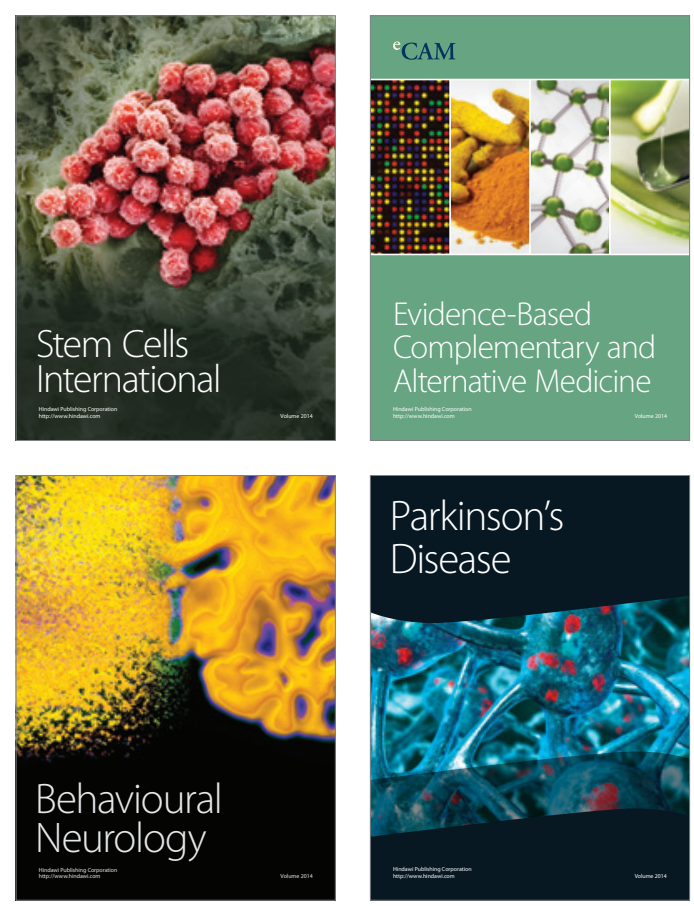

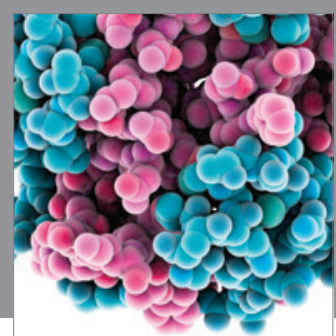

Journal of
Diabetes Research

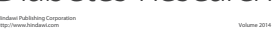

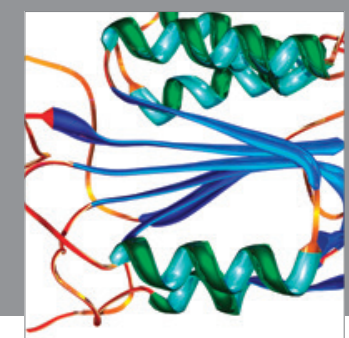

Disease Markers
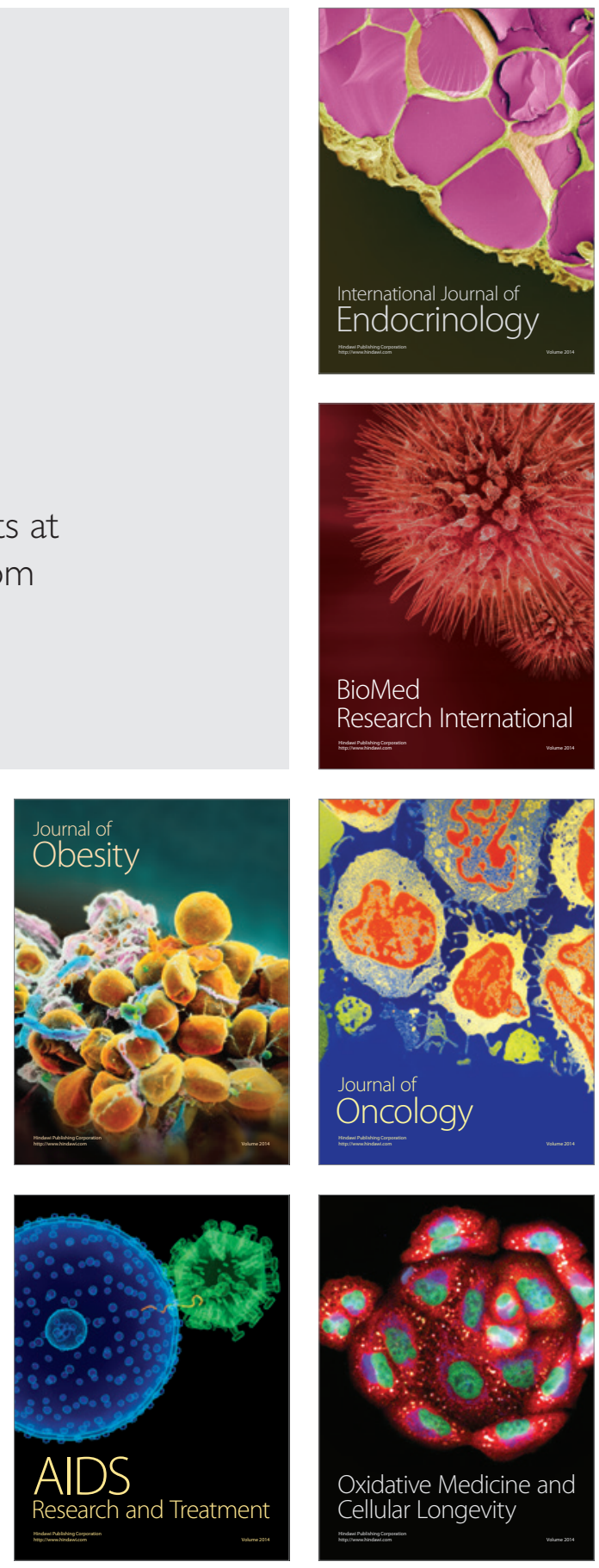